\title{
THE IDEAL OF KALOKAGATHIA OF THE TOTALITARIAN AND LIBERAL REGIMES AS A MEANS OF PERSONALITY FORMATION
}

\author{
Iryna Kobzieva ${ }^{1}$, Tetiana Prykhodko² ${ }^{2}$ Tetiana Kunicheva ${ }^{3}$, Jakub Korolevsky ${ }^{4}$, \\ Vanika Grover $^{5}$ \\ ${ }^{1}$ Cycle commission of economics, Management and Administration, Kharkiv College of Trade and Economics Kyiv National University \\ of Trade and Economics, Kharkiv, Ukraine \\ kobzeva0501@gmail.com \\ ORCID: http://orcid.org/0000-0001-8543-6599 \\ ${ }^{2}$ Cycle commission of economics, Management and Administration, Kharkiv College of Trade and Economics Kyiv National University \\ of Trade and Economics, Kharkiv, Ukraine \\ tanya150378@ukr.net \\ ORCID: http://orcid.org/0000-0001-9679-8878 \\ ${ }^{3}$ Scientific and Methodical laboratory, Kharkiv College of Trade and Economics Kyiv National University of Trade and Economics, \\ Kharkiv, Ukraine \\ tatkunicheva1@gmail.com \\ ORCID: http://orcid.org/0000-0001-6545-348X \\ ${ }^{4}$ International Coordinator, Vocational Higer School of Health, Beauty and Educarion in Poznan, Poznan, Poland \\ Kharkov@htek.com.ua \\ ORCID: http://orcid.org/0000-0002-0877-5025 \\ ${ }^{5}$ College of Educarion at Michigan State University, East Lansing, United States \\ ORCID: http://orcid.org/0000-0002-9773-1488
}

\section{ARTICLE INFO}

Article history:

Received date 11.05.2020

Accepted date 16.06.2020

Published date 30.06 .2020

Section:

Communication Studies

D O I

$10.21303 / 2313-8416.2020 .001336$

\section{KEYWORDS}

liberalism

totalitarianism

harmonious human development

\section{ABSTRACT}

The object of research is the relationship between the state and the individual under totalitarian and liberal regimes.

Investigated problem: in the article the concepts of totalitarian and liberal regime is analyzed, their nature and relation are revealed. The characteristics of each of them are considered. It highlights the impact that they have on the ideal of kalokagathia is highlighted. In a society in which the ideas of kalokagathia can be realized, there must be freedom, which is the most important value of the individual. Both directions of democratic thought - totalitarianism and liberalism welcome the higher value of freedom.

A person can't independently distinguish what is good, harmonious for it, and what is evil, it is not able to make competent decisions, it is always under the influence of the outside world and its conditions. Political regimes can be considered to a large extent, as the basic conditions for human existence. In some cases, these conditions can both stimulate a person and suppress it. This can lead to the fact that government agencies of direct action and coercion can make decisions for it or give rise to the right of permissiveness and thought only of oneself.

The main scientific results: historically, the state is called upon to realize the protective function of comprehensive harmonious human development (the ideal of kalokagathia) at the national level, but under the conditions of the presented regimes, this process undergoes various transformations and can't be fully realized and does not correspond to reality. The harmonious development of man is always full of dissonances and struggles of various forces in the human being.

(C) The Author(s) 2020. This is an open access article under the CC BY license http://creativecommons.org/licenses/by/4.0).

\section{Introduction}

\section{1. The object of research}

The object of research is the relationship between the state and the individual under totalitarian and liberal regimes.

\section{2. Problem description}

The long process of harmonious development of the individual has always been the key to an independent society and state. A more perfect and independent man is a value for the development of the progress of all mankind. The very idea of harmonious human development - the ideal of ka- 
lokagathia has always been transformed, both internally and externally, the ideal was quite flexible and later in its development had several historical modifications [1, p. 22-28]. Significant changes in the emphasis occurred under the influence of changing political regimes in the state and society. Man is always formed in the political environment and political regimes. Aristotle also remarked that «Man is by nature a political animal, who lives outside the state is either an underdeveloped being or a superman». «The state... by nature precedes each man... it is necessary that the whole precedes the part» «Nature instilled in all people a desire for state communication, and the first to organize this communication gave humanity the greatest benefit. Man, who has found its completion, is the most perfect of living beings» $[2$, p. 8$]$.

Political regimes play a special role and contain the volume of human rights and freedoms, the nature of the relationship between the state and civil society. «People are not born with readymade social norms, they absorb social values as they grow» $[3, \mathrm{p} .85]$. The division of political systems occurs outside the interference of the authorities in the regulation of public relations. According to this criterion, liberal and totalitarian regimes are distinguished. Totalitarian and liberal theories to a greater or lesser extent touch on the ideals, benefits, moral and physical values of man and the mechanisms of their regulation. This allows to reveal the ideals of kalokagathia in general, as a key doctrine of liberals and representatives of the totalitarian regime. This understanding reflects the original desire for the ideal of harmonious human development in terms of its interaction with the state.

\section{3. Suggested solution to the problem}

A significant contribution to the research of political regimes and their general scientific and philosophical justification has been made by both foreign and Ukrainian scholars. Among them: J. Quermonne, who in analyzing the essence of political regimes, relied on such defining indicators as the form and role of the state. The types and political regimes depend on the content and their correlation [4], J. Locke, he studied the theory and practice of separation of powers and institutional approaches to the interpretation of democracy [5], G. Spencer devoted his work to the ideological origins and doctrine of classical liberalism [6], Z. Brzezinski was the founder of the theory of totalitarianism in his book «Totalitarian Dictatorship and Autocracy [7], V. Lisovy investigated the problems of the development of a person's political culture from the point of view of generalizing political and psychological characteristics of an individual. He watched its ability to implement political knowledge in any political system [8].

The aim of study is a philosophical analysis of the phenomenon of totalitarian and liberal regimes, as well as the identification of their influences on the formation of harmonious human development.

\section{Materials and Methods}

The methodological basis of the study is the methods of philosophical and anthropological analysis and historical and philosophical reconstruction. The hermeneutic approach to the interpretation of the philosophical text is also used.

Each man, by nature, is characterized by a movement towards a specific goal, which is good, and virtues are necessary means for it to achieve good. The fullness of a good life is possible only within a society that requires the necessary conditions and the development of certain moral and physical abilities. In an environment in which the ideas of kalokagathia can be implemented, there must be freedom, freedom which is the most important value of the individual. The ideal of kalokagathia, as an idea of the harmonious coexistence of high intellectual, physical and moral qualities, guided human aspirations at different times, but at the same time was forced to submit to the behavior of individual political regimes that existed at that time.

The notion of «political regime» is more widely used in political science. It is the broadest and at the same time the least defined, so it is difficult to provide an unambiguous universal definition of the term. But there is a generally accepted text of this concept, which can be characterized as a means of the relationship between power and people and a means of regulating these relations. The most common typology of political systems includes totalitarian and liberal regimes. In both totalitarian and liberal societies, human freedom was present. But in its different sense. It is possible to immediately say that in a totalitarian society there is no place for freedom, and therefore 
for the harmonious development of man. But some scholars are not inclined to such a judgment and express the opinion that «totalitarian domination is aimed at the abolition of freedom, even the destruction of human spontaneity in general, and not at all to restrict freedom, no matter how tyrannical it may be» [9, p. 528]. Although, in essence, totalitarianism is deeply hostile to liberalism.

Totalitarianism alone does not have a sufficiently theoretical basis. It can't claim to be a profound philosophical theory, as it is nevertheless a more political program for practical action. The theory of the emergence of totalitarianism, as a phenomenon, has a long history. The idea of an «absolute» state that controls everyone and everything has existed for many centuries. Elements of totalitarianism were present in the projects of the «ideal» states of Plato, T. Mora, T. Campanella. totalitarian concepts can be traced in the philosophical literature of E. Zamyatin, A. Kestler, J. Orwell, F. Borkenau, N. A. Berdyaev. It is well known that the term «totalitarianism» is perceived by the social sciences and humanities on the characteristics of B. Mussolini and the regime he created. The phenomenon of totalitarianism was subjected to philosophical analysis in the middle of the twentieth century by the works of F. Hayek and H. Arendt.

Totalitarianism in essence essentially «dictates» to man acceptable options for behavior through the education system, the media, cultural norms, art and other spheres of life. In a totalitarian state, a man is comprehensively enslaved. The totalitarianism created by materialists rests on the animal-slave mechanisms of body and soul. Therefore, over time, the vast majority of citizens are no longer able to think independently, including about economic or socio-political reality. At one time, Plato, reflecting on the structure of the state, remarked: «The most important thing - no one should ever be left without a boss - neither men nor women. Neither in serious classes nor in games should anyone teach themselves to act at their own discretion.... for example, on its orders to stop, go forward, start exercising, wash, eat .... In short, let the human soul acquire the skills not to be able to do anything apart from other people and not even understand how it is possible» [10, p. 141]. It is this identification of man with the state that is the basis of a totalitarian regime.

Totalitarianism is a historically inevitable phenomenon. «To become free, to acquire the ability to self-government, all peoples had to go through prior strict discipline and submission to the master» [11, p. 248]. Totalitarianism is based on the concept of «man of the masses» and turns society into the sum of equivalent little we.

A man, especially a young man, according to the requirements of a totalitarian regime should be transformed into a new type. The task of upbringing was to deprive it of its past, and then to eliminate outside influences, such as family, family and close environment. Examples of the upbringing of such a man are the ideology of the Third Reich, the youth organization «Hitler Youth» (this organization was integrated into the system of the «Third Reich»), the main virtues of man were devotion, loyalty, willingness to sacrifice and the ability to remain silent. «The main task is not to pump our children with a lot of knowledge, but above all to raise completely healthy people. Only in the second place let's think about the development of spiritual abilities... and only in the last place let's think about school education ... It is better to be ignorant than weak» [12, p. 313].

In some studies of various thinkers in a totalitarian society, human mental activity becomes associative, there is a division into «own» and «foreign». It becomes very easy to convince a man of what is good and what is bad for it, the criterion of good is the service of the idea, the master, as the virtue of devotional service. Carriers of totalitarian thinking tend to be moral absolutists, dividing the world only into white and black... [13, p. 96]. The totalitarian system easily manipulates consciousness, resulting in the process of deformation of manality. From the point of view of A. G. Tauberger, the totalitarian type of thinking became widespread due to the loss of religious consciousness. Any religious repression is a form of totalitarian pressure on the independence of human choice. The first to be deformed is human consciousness. Human consciousness is filled with state ideology. There is a general and systematic pressure on the individual, it in some way changes the complex of motivations, actions and actions of man. The consciousness of the individual acquires the features of reality, which affects it. And here comes the concept of totalitarian consciousness. This name should be understood as the reflection and assimilation of a certain social reality. It is characterized by an internal contradiction of its essential basis and real ways of its manifestation - low self-esteem and hypertrophied overestimation, egocentric thinking and excessive trust in the collective mind. All this was an inevitable consequence of the contradictions between the official state ideas and the real way of life [14, p. 52]. 
For totalitarianism, the ideal of a comprehensively developed man, that is, the ideal of kalokagathia, is the center of evil. Such a state is usually wary of people who are intellectually, spiritually and physically gifted, because stupid people are much easier to manage. One great man recalls the idea that: «A man who has never gone to school may steal from a freight car; but if it has a university education, it may steal the whole railroad».

Any state always contains a totalitarian potential, intervenes in the development and livelihoods of people, because even the most democratic country seeks to expand its functions and powers, increase control over public affairs and reduce control over itself. All this is reflected in the direct carrier-man and its inner world.

Actually, by nature, a totalitarian consciousness is alien to man. But it can create the illusion of order and provide it with answers about its sense of being. Scientific and technological progress is beneficially contributing to this, which makes it possible to realize, with the help of huge means and methods of various technologies of the formation and manipulation of public consciousness, hidden control over human life within the framework of an allegedly democratic system. And today's greater human awareness can lead to the rejection of the universal values of cultural heritage. This progress poses a serious danger to humans. Therefore, one should not neglect the fact that the emergence of such a system is impossible in modern society or civilization, in which human needs for good are put in the first place. Although in the modern world, in the context of the global transition to the information society, totalitarianism is extremely unpopular and is gradually evolving towards liberal democracy.

Another view of the ideal of kalokagathia in the ratio of state and man was formulated with the emergence and establishment of liberal theories. Full-fledged liberal movements arose in European countries of the XVII-XVIII century, during the Enlightenment (France, England) and America. Liberalism was a counterweight to the arbitrariness of power, lawlessness, dictatorship, totalitarianism and began to take on different shades.

If totalitarianism is more or less an unambiguous concept, then, as far as liberalism is concerned, it is a multifaceted phenomenon and is used in various meanings. Liberalism is constantly evolving and has a transformational character, which is associated with the new needs of the individual. It contains opposite directions. These include: criticism by classical liberals of the application of coercive redistribution policies and rejection of moral principles under the guise of neutrality (conservative liberals).

But despite all the contradictions, the main idea of liberal concepts was the equal rights of all people: «Nature created people equal in terms of physical and mental abilities ... the difference between them is not so great that one man, based on it, could pretend to some kind good for itself ...» [15]. At the same time, the thinker, in the spirit of its time, focuses on the fact that the equality of people manifests itself more when it comes to mental abilities, rather than physical strength. Possessing the mind, a man will be able to figure out what is good for it and what is bad.

The liberal thinkers saw the achievement of a harmonious state in the maximum and complete satisfaction of their immediate material needs and desires, whether they be false or not, in spontaneity, in each man's independent attempts and mistakes, and in the absence of coercion, greater freedom to make independent decisions. Only a free man can find the best solutions for its own life, for its own well-being.

Regarding the harmonious development of the inner, spiritual and metaphysical needs of man, they were not the primary tasks for liberal values. This led to many questions from critics: «Even the greatest earthly riches can't give man happiness; they leave its inner self, its soul, unsatisfied and empty» (Ludwig von Mises). All people are equal as spiritual individuals, capable of moral improvement, and therefore have the same rights to life, the satisfaction of their own interests and the development of their abilities [16, p. 45-148]. In their defense, the liberals proclaimed that «the highest and the deepest in man can't be excited by any external regulation. Liberalism tries to ensure only external well-being, because it knows that internal, spiritual wealth can come to a man not from outside, but only from the depths of its own heart» [17, p. 23]. In turn, David Hume believed that the natural laws of human behavior dictate moral standards that can't be limited.

A famous representative of Ukrainian liberalism of the XIX century. Mikhail Drahomanov, under the influence of European liberalism, created and proposed an idea-concept of 
society based on the principle of association of harmoniously developed individuals. However, during the nineteenth century, the ideal of a harmonious man, as imagined by liberalism, degenerated into a one-sided specialist who no longer had any connection with society. The precedence of individual needs of the individual to the collective goals of society, led to the achievement of useful interests, the spread of selfishness, greed, the closure of the world, both social and manal, and to spiritual and moral impoverishment. Liberalism has never demanded moral self-improvement from man. Here the equality of good and good is applied; morality, which is formed by the opinion of the majority and discriminates against the minority, which does not share the moral values of the majority. The deterioration of liberalism began with the mixing of goals and means, with the substitution of the spiritual goals of life by material means. Therefore, in modern times there is a need to turn to new attitudes that would be based more on morality, which would unite society. But the concept of moral growth of man is possible only due to the liberal values realized in society. John Henry Newman believed that manality is the result of a liberal regime.

As it is noted above, in modern society, the conditions for the harmonious state of man is the possession of material property, which is the most important circumstance of the ideological cause of the extinction of economically prosperous peoples.

\section{Results and Discussion}

Learning from historical mistakes, let's understand that it is necessary to pay much attention to the enrichment of the individual morally, spiritually, and not just physically, and instilling in man an effort for good and truth. The influence of the outside world in many cases does not stimulate, but suppresses the development of young people's abilities, especially in situations where the living environment is meaningful, useful and interesting. In modern society, the conditions for the harmonious development of man are the possession of material property, which is the most important circumstance of the ideological cause of the extinction of peoples who prosper economically.

To solve the problems of interaction between the individual and the state, great religious teachings put forward their theory and advise that the state disappear if a person becomes attached to it so much that welfare and power and glory of the state become criteria for good and evil. This theory was severely criticized by E. Fromm in his book Psychoanalysis and Religion. Another great thinker, Hobbes, believed that good and truth should be instilled in a person only through the threat of violence, with the strong hand of the ruler.

In our opinion, the state and its political regimes will be able to positively influence a person when they themselves become legitimate, that is, moral, will have moral authority and inspire respect with the maintenance and building up of historical traditions.

\section{Conclusions}

Summing up the above, it is possible to state the following: historically, the state is called to implement the protective function of comprehensive satisfaction of human development at the national level. Humanistic tendencies are aimed at recognizing a man as the highest value, raising the general standard of living, creating conditions for the comprehensive, harmonious development of the individual. The influence of the outside world in many cases does not stimulate, but suppresses the development of young people's abilities, especially in situations where the living environment is meaningful, useful and interesting.

Today it is a very popular opinion that a man can't independently distinguish what is good, good, harmonious development for it, and what is harmful and why it is not able to make competent decisions, so it leads to what is being taken for it, decisions of state institutions. In such a situation, it is possible to follow the path of direct action and coercion (but here the question arises whether coercion will disappear when a man reaches its harmonious state?) or by classical liberalism of permissiveness and thought only of oneself, of one's manality, and not of society as a whole. This provides an element of freedom, it is human freedom is assessed as a key value, but then a man moves independently, as it wants, according to the principle dictated to it by the state: «Your life your problems» Therefore, it is necessary to stop and immediately rethink our actions because only it is possible to move into a qualitatively new phase of our own development. 


\section{References}

[1] Aristotle (2016). Politics. Moscow: AST Publishing House, 384.

[2] Kobzieva, I. O. (2018). Harmonic aspects of kalokagathia: historical and philosophical analysis. Osvitology, 7, $22-28$.

[3] Soros, G. (1999). The Crisis of Global Capitalism: Open Society Endangered. Moscow: INFRA, 85.

[4] Quermonne, J. (1986). Les regimes politiques occidentaux.

[5] Locke, J. (1690). Two Treatises of Government. Available at: https://www.yakaboo.ua/ua/second-treatise-of-government.html

[6] Spencer, G. (1884). The Man Versus the State» Available at: http://econlibrary.ru/books/90/79/spencer_person \%20and \%20 state.html

[7] Brzezinski, Z. (1956). Totalitarian Dictatorship and Autocracy. Cambridge: Harvard university press, 438. Available at: http:// web.archive.org/web/20071010203916/http://auditorium.ru/books/1224/ch2r2.pdf

[8] Lisovy, V. (2006). The concept of political culture. Political culture of Ukrainians.

[9] Arend, H. (1996). The Origins of totalitarianism. Moscow, 528.

[10] Popper, K. R. (1992). Open Society and its Enemies. Vol. 1. Moscow, 204.

[11] Hegel, G. V. F. (1977). The Encyclopaedia of the philosophical Sciences. Vol. 3. Moscow: Thought, 471.

[12] Adolf Hitler (1992). My struggle. Publishing house«T-Oko», Lobanov S. N., 313.

[13] Tauberger, A. G. (2003). System-functional analysis of totalitarianism. Novgorod, 173.

[14] Polezhaev, D. V. (1996). Totalitarianism and manality mentality. Volgograd, 151.

[15] Hobbes, T. (2001). Leviathan: or The Matter, Form, and Power of a Commonwealth, Ecclesiastical and Civil. Available at: https:// royallib.com/book/tomas_gobbs/leviafan_ili_materiya_forma_i_vlast_gosudarstva_tserkovnogo_i_gragdanskogo.html

[16] Ilyin, I. A. (1994). General doctrine of law and the state. Collected Works. Vol. 4. Moscow: Russian Book, 45-148.

[17] Mises, L. von (2007). Liberalism. Moscow: Sotsium, 344. 